\title{
Coexistence, co-responsibility and interdependence as categories important to social pedagogy directed towards building local communities
}

\section{KEYWORDS}

Coexistence, shared responsibility, interdependence

\begin{abstract}
Naumiuk Agnieszka, Coexistence, co-responsibility and interdependence as categories important to social pedagogy directed towards building local communities. Culture - Society - Education no. 1(17) 2020, Poznań 2020, pp. 63-72, Adam Mickiewicz University Press. ISSN 2300-0422. DOI 10.14746/kse.2020.17.3.2
\end{abstract}

The article analyzes three categories: co-existence, coresponsibility and interdependence in the context of contemporary discussions about the role of social pedagogy in building local communities. New possible approaches arise while using these concepts for addressing contemporary conditions of the communities which result in new tasks of education. There are analysed also the consequences of the transformation from the previous rather static (territorial) view of local communities, that had the aim to root people in existing social structures, towards more dynamic, open and diverse spaces. They are not considered only as physical places anymore but as new local relations that are being developed, based on not stable, however increasingly popular forms of sharing experiences. For these changes the studied concepts match the new realities and in consequence demand pedagogical considerations.

* Orcid https://orcid.org//0000-0001-5390-4263. 


\section{Introduction}

Building local communities is a constant process that seems rather blurred. In consequence there is the difficulty in setting specific goals and criteria for the effectiveness of the actions taken in this area. This concept, however, has become one of the key issues of the European Union in recent years (EU Cohesion Policy, 2014, see also Banaszak, 2014), because even the most efficiently managed local systems understand the additional need of citizens for a communal sense of closeness, security, life in the atmosphere of kindness and trust, despite that it still seems to be a distant dream (Bauman, 2008: 5-11).

Poland, where the family and nation/country have been for centuries the main reference points in the validation of interpersonal relations, had in fact many geo-political difficulties in shaping integrated local spaces and build traditions of a sense of community. Even though there were and still are beautiful examples in some places, still in the overall societal development, this aspect is missing. Therefore, the question that social pedagogy raises on what is the sense of community role and its development and organizing, seems particularly important in our country (Radziewicz-Winnicki, 2013; Skrzypczak, 2016). Discussions on the meaning of common life in the meso-social scale, constantly returns and demands answers in the form of specific contemporary solutions, but it also appears in the ethical considerations about the fundamental values in relation to the roles of educators (Theiss, 2018: 118; Pilch, 2018: 39; 50-52). After thirty years of building new conditions of social change, Polish democracy seems to be mature enough to probably assess more objectively the pro-social activities' functions and distinguish from perceiving tchem as a result of external control or coercion, or as a result of internal need for relationships building with others, through true participation and aspiration to experience ousrelves as social beings.

Many valuable local and neighboring initiatives have been launched rather quickly, both in the form of independent grassroots activities and in the form of projects of various institutions (Szczurek-Boruta et al., 2014; Segiet et al., 2017; see also projects such as those initiated by the Academy of Philanthropy Development or CAL Association ${ }^{1}$ ). They aim at people's understanding of they share in common, through getting to know each other in the communities, creating relationships, understanding each other not only in the individual but also in a collective context. However, this is not an easy task in the period of specific processes

\footnotetext{
${ }^{1}$ See: http://www.cal.org.pl/english-version/ and http://dzialajlokalnie.pl/about-act-locally-program.
} 
of creating new global language, visible in particular terms and formulas appropriating or simplifying the concept of community. In addition, new tendencies apear - to interpret local actions in the view of nationalism, exclusion and in essence, through fight against the common ideals of democracy (Mendel, Naumiuk, Skrzypczak, 2018).

The unceasing task of social educators has been to observe the conditions of the development and change of local traditions in maintaining social and cultural ties, and to reflect on which of them, how and under what principles, can and should be included in the deliberate assumption. In particular - which are only sham activities and which, in fact, deny the ideals that constitute the foundations of an integrated community (see Dryżałowska et al., 2019; Segiet et al., 2017).

\section{Changes in perception and interpretation of the dynamism of the local community}

As social educators, we have become accustomed to using specific terms that are inscribed in the canon of our discipline, without which we can not imagine building our professional research identity, implementing specific ideas in practice, or discussing the role of education in the local environments. In our pedagogical overwiew it is important to realize how we treat and interpret certain concepts, because they constitute a conceptual framework for the adopted ways of seeing the reality. Such an interesting term, which seems also a challenge for contemporary interpretations, is the category of "pedagogy of co-existence", was previously for description of innovative ediucation at schools (Dymara, 2014). It is now expanding in the areas of community education and in describing activities, where various inspirations of this term are reflecting on acts in the local life and in potenial functions of social pedagogy.

It seems that some solid, traditional formulas used in our country in the past are still unclear to us and seem incomplete. For some researchers and practitioners, it is a challenge to define the opportunities and to see the elements of new qualities that shall cross the boundaries of standard thinking about locality. This is the case, with many years of dilemmas of understanding, defining and using the term "local community", that there is a problem of identifying the object. Thinking in terms of language analysis, we have the noun: community, and its attribute: local, which are directing our thinking towards a certain social beings, living in a limited area of physical space. This sociological approach is limited and the use of Western concepts does not help. We try to present a range of features and give 
social sense to this phenomenon in Poland, determine the ways of analysis and of cultural backgrounds, introduce the traditions and forces modeling educational processes there (eg. Smolińska-Theiss, 1991; Theiss, Skrzypczak, 2006). We are investigating, therefore, the characteristics of our collective consciousness resulting from the adaptation of these collective community principles, to match them best to our pedagogical intentions and make a local environment the socio-educational platform (Winiarski, 2006; Winiarski, 2017).

Dilemmas grow when we become aware that, as Tadeusz Pilch points out, the concept of the local community is not identical with the concept of the local environment, although they are used interchangeably and have similar but not identical designates (Pilch, 2006: 413). In consequence social educators, throgh their work "with the local community" or "for the local community", use this term mostly as as a certain space of action for the development of individuals and groups (e.g. Bąbska, Rymsza, 2014).

Obviously being aware of the fact that we think and speak with abbreviations, we still treat this "collective existence" rather in enigmatic and stereotyping ways. In practice, questions arise about the applicational dimensions of such widely understood and unclear area of pedagogical tasks, ranging from defining community needs, recognizing its potentials to the so-called best practices, which in turn cause a series of further generalizations, stereotyping reinforcements, examples derived from the context. There are attempts to map, categorize, systematize the communities' characteristics in the areas of observed but difficult for simple descriptions phenomena, that make up its dynamic diversity (see Gliński et al., 2004). In some considerations, the local community becomes only a space in which individual beings function. The task assigned to social educators nowadays, is then to shape the space that favors mostly the individual development, as opposed to former directions to build homegic community, without respecting someones' individuality. We shall cosider then, how the proposed dychotomy: individuality vs. community, could be replaced with the perspective of complementary processes shaping the same human being: in his/her individual and collective (social) dimensions. This area involves also the anticipation of the future life with the task to avoid the danger of simplifying the community concept by folklorisation or sentimentalism of the past as opposed to dynamism of the future. This can be realized by showing the importance of integrated approach understood as collective "memoryplace" (Theiss, Mendel, 2018), showing the value of individual and diverse emotions, memories and hopes present in one place. 
Meanwhile, there has been a change happening in the way of seeing the world and local communities. Modernity demands a change of paradigms, freeing space into thinking about non-places (the concept of Marc Auge) noticing the perspectives of being in many places at once, augmented / expanded realms with virtual space thanks to the digital world (Dejnak, 2012), and transforming a flat image of homogeneity and one-dimension reality of social phenomena, into a variable, multidimensional, heterogeneous flow structure described by Manuel Castells (Castells, 2010). It is necessary to change then the pedagogical goals from the pursuit of targeting states seen as the simple effects of educaction and upbringing in certain territory, into processes perceived as educational transformations of open space knowledge flow. In hyper-modernity, the "pedagogized" being is escaping from pedagogical control to various forms of creative emancipation, that in turn expects from pedagogy, a new understanding of closer relationships and demands for co-existencing and co-creative new educational manners and forms. They no longer wait for plans or policies from the top to be accepted by the "bottom" and principial solutions offered by educational institutions.

In social sciences, the symptom of perceiving this change is visible in the increasingly popular participatory research and multidisciplinary approaches (Theiss, 2008: 74-77; Gierczyk, Dobosz, 2016) more strongly emphasizing various types of partnerships of the institutions of practice with groups of citizens. World trends, reflecting these mechanisms, lead to the dissemination of the idea of co-construction of reality and co-production of srevices as well as co-governance in politics as ideas guiding the revision of paternalistic, protective ways of treating disadvantagedor less independent groups, however, these ideas do not allow completely the free bottom-up, claiming rights' movements, occasionally separating or selecting the right to live in diversity (eg. various kinds of local nationalisms).

\section{Searching for pedagogical functions of local development based on the categories of coexistence, interdependence and co-responsibility}

It may be easier for pedagogues to focus on relational structures by actively assisting in the mutual communications and common implementations of a specific activities or planning towards the environment change and more communal base development. Social pedagogy is constantly researching the phenomenon of social relations that have the potential to educate, develop and change. Classical notions of social forces, human impact but also ties, social networks, individual and social 
capital, presented in pedagogical debates, have been suggesting for years, the importance of this area for considerations towards value of development in a local perspective (e.g. Szczurek-Boruta et al., 2014).

The term co-existence adds another important feature to educational issues in this area. It presents an ontological perspective accompanying the approach to the issue of a person inseparaby connected with others. Being with others or even being "for" others does not always means being "together" and being together, does not necessary mean creating (or being part of) a community. Martin Luther King, spoke about this difference, when he showed that it is not enough to be someone's neighbor, pass or stay along someone, to understand him, sympathize with his problems and help him if necessary (King, 1963). The term co-exstence introduces and suggests a certain dependence and indissolubility of various fates merging in the intellectual, emotional and physical dimensions. As Bronisława Dymara points out in the concept of pedagogy of coexistence, not only the cognitive but also emotional aspect is included, covering all interpersonal spaces (Dymara, 2014: 35). Only this type of experiencing, thinking and acting can indicate real social integration, which is produced centrifugal, through human intentions resulting from understanding and the common connection of our fates. Not necessarily it is internalised through the channel of even most glorious inclusive efforts of external institutions that use a variety of motivating, punitive, rewarding or enforcing laws that set the formal framework for what is just.

The educational thought and the analysis of an approach to the idea of coexistence, requires deeper reflection, and forces us to verify our so far used pedagogical tools. The educator facing any task, when he/she needs to answer the question on integrated community action, is now experiencing new situations, when he/she as person influencing the change needs to revisit past habits and face the new claims that demand more of the common life. It is envisioned in the following expectations: "we as co-creators of the environment/community" and "we as co-recipients of services". These are in fact the co-influences. A paradox of searching for individual rights while demanding collaborative participation is a challenge in neoliberal modernity. The proper response can not be taught, because it is a perspective not so much about modeling and transferring knowledge or forming attitudes, but about joint experience. Therefore, co-existence as mutual "being" is connected with co-experiencing, co-feeling, co-creating but also taking co-responsibility for what we change as pedagogues together with other professions. There isn't probably more democratic and more demanding social (collective) self-awareness of the consequences of this matter than this one. The prefix "co-" is shaping participative, emancipating and creative potential, but at 
the same time leads to new obligations and dependencies (and thus to interdependence and co-responsibility).

In such a concept of living together and understanding our common existence, there is a new meaning then for discussions and discourses. Consequently, the opposition and resistance are transforming from "against" something or contradictory to it, to the similar path "towards...", a direction that might be diverse but at the same time creates our common, pararel human experience. Therefore, these categories are important for social educators, not so much for creating a community that is ideal and perhaps will never be achieved, not even for a communal (communitarian) thinking, which requires some broader competences that many communities in Poland are still trying to develop, but for creating foundations for planning to build new or rebuilding existing local spheres.

In pedagogy we can distinguish at least three areas in which these categories of coexistence, interdependence and co-responsibility are significant (although there are certainly many more that could be mentioned):

1) axiological area in the aspect of what is the priority /important in upbringing in the context of mainstream assessments evaluating specific activities and understanding what it means "common/ together" in the dialogical dimension: I - You, We - They, I - We and personalistic in relation to building in-depth relationships and in classic thought, though perhaps a bit idealistic vision of Jack Delors shown in the concept of Education for All (in the first of four pillars, ie "to learn to live together") (Dymara, 2014: 36);

2) formation area in the development aspect, in which understanding of a person in relation to others is contained in his/her real experience (John Dewey) and subjected to reflection, favoring the development of a human being as a bio-psycho-social phenomenon (Helena Radlińska), which creatively develops and tranformatively learns (Jack Mezirow) while being at the same time a person being modeled, and the one that has the potential to form others;

3) the area of activity pragmatics (communication, social education) - based on mutual understanding, respecting different goals when establishing a common pursuit of development beneficial to all, as an exemplification of the functioning of a heterogeneous social world guided by the principles of pluralism, in which there is room for everyone.

In these different dimensions, care and sensitivity, respect and empathy that are built on natural social relations and based on the principles of social solidarity and human rights, are emphasized. In such perspective, instead of power relations and authoritarian inclinations, we introduce a new quality of recognition of some- 
one's right to participate. Participation provides application, not just ideological understanding of the prefix co- before any desired word, but planting these foundations with the conviction that building local communities is a process of constant readiness to participate in specific activities due to the need to be, and the value of being needed. To this readiness, we shall prepare ourselves and others to create conditions conducive to its occurrence. At this point, it can be stated that in the context of the tradition of Polish social pedagogy, this sentence indicates the closure of more than a century of reflections on the role of education in the environment and the return to the beginnings of creating this discipline in our country.

New reality, however, indicates that there is still a strong need to discuss how social educators can, want, have ambitions, to participate at a local level in change, requiring co-creation and cooperation, that the direction of this change is as friendly to all of us as possible, perhaps in a more psychological way than any other, but simply gives us the joy of being with other people. This internal joy can not be created even by the most effective social programs, and the most colorful neighborhood projects or the wisest scientific discussions. It is a challenge facing the theory and pedagogical practice, which should neither diminish nor complicate the world based on trust, kindness or a sense of security in the situation of being with others. Perhaps the unsurpassed dream of "a country/nation of friendship" (Rzeczpospolita Przyjació - term after Adam Abramowski) is an utopian vision that is seducing with its idealism, but it has an element of a call for transforming the actions towards the environment that is communal, guided by our ideals - which is present in the classic and more pragmatic formula of Helena Radlińska. It shall be no longer treated as the uthopia, because it means a realistic call for change towards what we inspire to, as social beings. The change which contemporary social pedagogy could do and sees using the categories of coexistence, interdependence and co-responsibility.

\section{Conclusions}

Previous (mainly territorial) ways of seeing local communities were aimed at supporting adaptation, embedding in existing social structures. Nowadays they are changing towards more dynamic and open, diverse spaces, where new "local" relations are developing, based on increasingly more widespread forms of sharing experiences. The threat of certain negative effects of the new tribalism (see Maffesoli, 2008) can be overcome by conscious work in new environments that need 
to be better understood and function more freely. The new local upbringing reality has not only separated from the specific territory, but also caused the change of former top-down relations of the educator-pupil into more partnership like relations. This in turn also leads to a change in the sphere of social and educational activities towards deeper cooperation, changing caring systems to mutual care systems, towards modifying responsibility of professional educators for education field, towards co-responsibility patterns. Pedagogues then shall develop new tools of dialogue with non-pedagogues who know the same and may even have bigger educational experience.

There is a high probability that while this direction will be maintained, reflection on the role of social pedagogy in the context of local communities will have to relate the existing methods of community work and take into account the participatory nature of emancipating relations that no loger treat others as less-educated, or less aware of educational angles but as consious partners that look for partnerships with pedagogues who can help them echieve their (understood as our common) goals.

\section{Bibliography}

Banaszak B. (2014), Unia Europejska jako wspólnota wartości, Przegląd Sejmowy, 4(123), pp. 9-21.

Bauman Z. (2008), Wspólnota. W poszukiwaniu bezpieczeństwa w niepewnym świecie, trans. J. Margański, Kraków.

Bąbska B., Rymsza M. (2014), Organizowanie społeczności lokalnej - metodyka pracy środowiskowej, Zeszyty Spraw Publicznych C.A.L., http://www.osl.org.pl/wp-content/uploads/2014/09/ Tryptyk-02_calosc-lekka.pdf, accessed: 2.08.2019.

Berger P., Luckmann T. (1983), Społeczne tworzenie rzeczywistości, trans. J. Niżnik, Warszawa.

Castells M. (2010), Społeczeństwo sieci, 2nd ed., Warszawa.

Dejnaka A. (2012), Rzeczywistość rozszerzona i jej zastosowanie w edukacji, E-mentor, 2(44), http:// www.e-mentor.edu.pl/artykul/index/numer/44/id/918, accessed: 1.08.2019.

Dryżałowska G., Kuleta-Hulboj M., Naumiuk A., Skura M., Steinhagen A. (2019), Inkluzja w perspektywie pedagogiki specjalnej i pedagogiki społecznej. Pytania, konteksty, dyskusje, Warszawa.

Dymara B. (2014), Źródła, cechy i perspektywy pedagogiki współbycia, [in:] U. Szuścik, B. Oelszlaeger-Kosturek (eds.), Dziecko w świecie innowacyjnej edukacji, współdziałania $i$ wartości, t. 1, Katowice, pp. 29-47.

Gierczyk M., Dobosz D. (2016), Możliwości metodologiczne w badaniach problemów społecznych perspektywa partycypacyjna, Pedagogika Społeczna, 2(60), pp. 151-165.

Gliński P., Lewenstein B., Siciński A. (2004), Samoorganizacja społeczeństwa polskiego: III sektor i wspólnoty lokalne w jednoczacej się Europie, Warszawa.

Kazimierczak T. (2012), Koprodukcja, czyli "prawo do miasta” w działaniu - jak poprawić partycypację publiczną przez udział obywateli w świadczeniu usług publicznych, Decydujmy Razem, 
Special issue 2, pp. 3-18, http://www.decydujmyrazem.pl/publikacje/decydujmy_razem_/ AiO_2_2012.html, accessed: 20.09.2019.

King M.L. (1963), On a good neighbour, [in:] B. Barber (ed.) (1999), Education for Democracy, Dubuque, Iowa, pp. 601-607.

Maffesoli M. (2008), Czas plemion. Schyłek indywidualizmu w społeczeństwach ponowoczesnych, Warszawa.

Mendel M., Naumiuk A., Skrzypczak B. (2018), W trosce o społeczeństwo. Pedagogika społeczna w czasach nacjonalizmu, Pedagogika Społeczna, 4(70), pp. 137-159.

Pilch T. (2018), Godność w przekonaniach i praktyce działania pedagogicznego, [in:] W. Danilewicz, J. Niktorowicz, M. Sobecki (eds.), Ku życiu wartościowemu. Idee - Koncepcje - Praktyki, t. 2, Kraków, pp. 37-53.

Pilch T. (ed.) (2006), Encyklopedia pedagogiczna, vol. V, Warszawa.

Polityka Spójności UE, Community-Led Local Development, https://ec.europa.eu/regional_policy/sources/docgener/informat/2014/community_en.pdf, accessed: 2.08.2019.

Radziewicz-Winnicki A. (2013), Społeczność lokalna, zbiorowość terytorialna, a instytucjonalizacja ideologii lokalizmu/regionalizmu, Rocznik Lubuski, vol. 39, part. 2, pp. 13-24.

Segiet K., Słupska K., Tokaj A. (eds.) (2017), Animacja w środowisku, O potrzebie kreowania działań lokalnych (teoria i praktyka społeczna), Poznań.

Skrzypczak B. (2016), Współczynnik społecznościowy. Edukacyjne (re)konstruowanie instytucji społecznościowych - w perspektywie pedagogiki społecznej, Torun.

Smolińska-Theiss B. (ed.) (1991), Węgrów. Sity społeczne małego miasta, Warszawa.

Szczurek-Boruta A., Chojnacka-Synaszko B., Suchodolska J. (2014), Człowiek w przestrzeni lokalnej-dobre praktyki wspierania rozwoju, aktywizacji i integracji społecznej. Konteksty teoretyczne, Toruń.

Theiss M. (2008), Participative Action Research. O roli "partycypacyjnych badań w działaniu” w polityce społecznej, Problemy polityki społecznej. Studia i dyskusje, 11, pp. 65-85, http://problemypolitykispolecznej.pl/images/czasopisma/11/11_65-85.pdf, accessed: 4.09.2019.

Theiss W. (2018), Helena Radlińska: powrót do źródeł i tradycji w ponowoczesnym świecie, Pedagogika Społeczna, 4(70), pp. 113-123.

Theiss W., Mendel M. (eds.) (2019), Pamięć i miejsce. Perspektywa społeczno-edukacyjna, Gdańsk.

Theiss W., Skrzpczak B. (eds.) (2006), Edukacja i animacja społeczna w środowisku lokalnym, Warszawa.

Winiarski M. (2006), Wspótpraca jako wymiar edukacji środowiskowej, [in:] W. Theiss, B. Skrzypczak (eds.), Edukacja i animacja społeczna w środowisku lokalnym, Warszawa, pp. 35-54.

Winiarski M. (2017), Środowisko wychowawcze i jego kształtowanie w kontekście pedagogiki społecznej, [in:] K. Segiet, K. Słupska, A. Tokaj (eds.), Animacja w środowisku, O potrzebie kreowania działań lokalnych (teoria i praktyka społeczna), Poznań, pp. 27-46. 